\title{
Qualitative Assessment of Concentrate Feeds of Dairy Animals for Indore District of Madhya Pradesh
}

\author{
C.S. Saksule ${ }^{1}$, Ravindra Kumar Jain ${ }^{* 2}$, Vishal Mudgal ${ }^{3}$ and Anchal Keshri ${ }^{4}$ \\ ${ }^{1}$ I.B. Group, Amravati, Maharastra, INDIA \\ ${ }^{2}$ Department of Animal Nutrition, College of Veterinary Science and A.H., INDIA \\ ${ }^{3}$ Division of Animal Nutrition, Central Institute for Research on Buffaloes, Hisar, Haryana, INDIA \\ ${ }^{4}$ Department of Animal Nutrition, College of Veterinary Science and A.H., Mhow, Madhya Pradesh, INDIA \\ *Corresponding author: RK Jain; E-mail:drrkjainvet@gmail.com
}

Received: 10 Aug., 2021

Revised: 20 Sept., 2021

Accepted: 24 Sept., 2021

\begin{abstract}
A survey of feeding practices among dairy animals of Indore District of Madhya Pradesh (MP) was conducted in all four tehsil of Indore District. Along with collection of common concentrate feeds being used in the area was done to assess their quality. It was indicated that majority of farmers were feeding wheat straw as roughage and cotton seed cake (CSC), wheat bran (WB) and compounded feeds as concentrate without supply of greens. Collection of 30 samples was done randomly for each feed from farmers, market dealers and feed manufactures and analyzed for proximate principals, acid insoluble ash (AIA), calcium (Ca) and phosphorus (P). The samples of CSC, WB and compounded feeds having nutritive value below their required specifications (BIS) especially in case of unbranded samples, while the branded once were almost within their expectations except the amount of total ash and crude fiber (CF), which remained higher then recommended. The unbranded samples of these feeds were usually lower in protein and high in CF and especially the compounded feeds were very high in total ash and AIA remains indicative of adulterations. Hence, BIS have to tack strict initiatives to control the quality of concentrate feeds and among them complete feed requires special attention to be paid.
\end{abstract}

\section{HIGHLIGHTS}

(0 Survey of feeding practices among dairy animals of Indore District of Madhya Pradesh.

(- Collection of common concentrate feeds being used in the area to assess their quality.

Keywords: BIS, Concentrates, Dairy animals, Indore District, Quality assessment

Feed quality is a "catch word" which everyone cherishes and likes to talk about, but practically very few maintain the same. The two main factors that directly related to animal performance and health are feed quality control and ration consistency. It would supply all nutrients in adequate quantity and of high ingestibility and digestibility. A number of surveys have been conducted to know the quality of feed available in the market (Singh and Kundu, 2003). Most surveys indicated lower level of nutrients present in the available feeds.

The missing link between production and production potential is that equal emphasis has not been given to feed resources and its quality. The quality of compounded feeds depends upon the quality of raw materials used in the finished product. Due to the huge gap between demand and supply, the feed millers and manufacturers are sometimes tempted to adulterate the feed ingredients by poor energy and poor protein materials. This will not only decrease the milk production but also adversely affects the health of

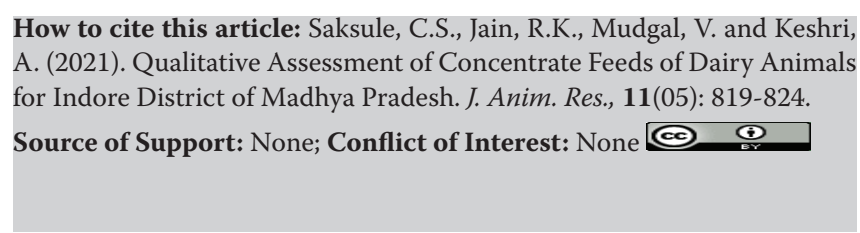


the animals. Presently, some of major constraints faced by the farmers and feed manufacturers in India are limited supply of quality feed ingredients, uneven prices as well as the competition offered for cereal grains by the ever increasing human population. The animal nutritionist's main concerns include availability of quality feed, problem of imbalance of nutrients in compounded feeds and the under-nutrition in livestock population.

In the Malwa region of M.P. the farmers are following traditional feeding practices. Cotton seed cake is the only cake being fed to dairy animals as a source of concentrate. Few farmers fed wheat bran and compounded feeds along with straw (wheat/gram/masoor) (Sharma and Jain, 2016). In such situation quality control of these feeds is essential. Therefore, the present study was carried out to find out chemical composition of common feed stuffs for dairy animals and to compare their quality with the BIS specifications.

\section{MATERIALS AND METHODS}

A survey of feeding practices in dairy animals was carried out in all four tehsils (Indore, Mhow, Depalpur and Sanwer) of Indore district of Madhya Pradesh (MP), during MarchApril 2009. Minimum sixty five farmers from each tehsil were selected randomly and information was collected on existing feeding practices in dairy animals.

Along with to assess the quality of concentrate feeds used for feeding to dairy animals in Malwa region of M.P., samples of concentrate feeds [ 30 samples each of branded and unbranded] were collected randomly from farmers, market dealers and feed manufactures from all four tahsils of Indore district. Samples were analyzed for proximate principals, AIA, $\mathrm{Ca}$ and $\mathrm{P}$ by the standard methods (AOAC, 1995) and urea in feed samples was estimated by using the method described by Lohan et al. (1998). The data were analyzed as per the standard statistical methods described by Snedecor and Cochran (1994) for mean, standard error and paired 't' test.

\section{RESULTS AND DISCUSSION}

The results of the survey conducted are presented on the Table 1.

Out of total dairy farmers maximum number of farmers $(31.72 \%)$ were feeding wheat straw + cotton seed cake + compounded feed, while the small number of farmers were also following other combinations like: wheat straw + cotton seed cake and wheat bran $(18.41 \%)$, wheat straw + wheat bran + compounded feed $(10.48 \%)$, gram straw + cotton seed cake + compounded feed $(13.59 \%)$, gram straw + cotton seed cake + wheat bran $(6.23 \%)$, wheat straw + cotton seed cake + gram chuni $(10.48 \%)$, gram straw + cotton seed cake + wheat bran $(5.94 \%)$ and masoor straw + cotton seed cake + wheat bran $(3.11 \%)$, respectively. It indicated that majority of farmers were feeding cotton seed cake, wheat bran and compounded feeds as concentrate without any greens. Similar types of observations were also made by Mudgal et al. (2003). The mean of chemical composition of branded and unbranded cotton seed cake samples are given in Table 2 .

The results revealed that the values of $\mathrm{CP}$ was lower than the recommended in the unbranded CSC, while both the type of CSC were having high amount of CF and EE and reduced NFE then the standard requirements suggested by BIS (2003a). High CF and low CP values indicated

Table 1: Survey of existing feeding pattern in dairy animals of Indore district

\begin{tabular}{|c|c|c|c|c|c|c|c|c|c|}
\hline \multirow[b]{2}{*}{ Tehsil } & \multirow[b]{2}{*}{$\begin{array}{l}\text { No. of farmers } \\
\text { visited }\end{array}$} & \multicolumn{8}{|c|}{ Pattern of feeding } \\
\hline & & $\begin{array}{l}\text { WS + CSC } \\
+ \text { CF }\end{array}$ & $\begin{array}{l}\text { WS + CSC } \\
+\mathbf{W B}\end{array}$ & $\begin{array}{l}\text { WS + WB } \\
+\mathbf{C F}\end{array}$ & $\begin{array}{l}\text { GS + CSC } \\
+\mathrm{CF}\end{array}$ & $\begin{array}{l}\text { GS + CSC } \\
+ \text { WB }\end{array}$ & $\begin{array}{l}\text { WS + CSC } \\
+ \text { GC }\end{array}$ & $\begin{array}{l}\text { GS + CSC } \\
+\mathbf{W B}\end{array}$ & $\begin{array}{l}\mathrm{MS}+\mathrm{CSC}+ \\
\mathrm{WB}\end{array}$ \\
\hline Indore & 78 & 29 & 10 & 8 & 11 & 5 & 8 & 4 & 3 \\
\hline Mhow & 140 & 48 & 24 & 17 & 24 & 6 & 12 & 7 & 2 \\
\hline Depalpur & 65 & 17 & 14 & 5 & 8 & 3 & 8 & 6 & 4 \\
\hline Sanwer & 70 & 18 & 17 & 7 & 5 & 8 & 9 & 4 & 2 \\
\hline Total & 353 & 112 & 65 & 37 & 48 & 22 & 37 & 21 & 11 \\
\hline Percentage & & 31.72 & 18.41 & 10.48 & 13.59 & 6.23 & 10.48 & 5.94 & 3.11 \\
\hline
\end{tabular}

CSC-Cotton seed cake, CF-Compounded feed, WB-Wheat bran, WS-Wheat straw, GS-Gram straw, MS-Masoor straw, GC-Gram chuni. 
Table 2: Mean Chemical composition of different cottonseed cakes (CSC) samples

\begin{tabular}{llllll}
\hline & Branded CSC & & Unbranded CSC & & $\begin{array}{l}\text { BIS (2003) } \\
\text { (Undecorticated Gr.II) }\end{array}$ \\
\hline Moisture & Mean \pm SE & CV (\%) & Mean \pm SE & CV (\%) & \\
$C P$ & $8.64 \pm 0.24$ & 8.35 & $8.35^{*} \pm 0.37$ & 9.07 & 9 \\
$E E$ & $21.66 \pm 0.22$ & 6.55 & $18.34^{* *} \pm 0.58$ & 6.92 & 20 \\
$C F$ & $8.77^{* *} \pm 0.13$ & 11.94 & $7.90^{* *} \pm 0.20$ & 7.23 & 5 \\
$N F E$ & $30.27^{* *} \pm 0.34$ & 7.23 & $30.23^{* *} \pm 0.57$ & 4.43 & 26 \\
$T A$ & $35.81^{* *} \pm 1.16$ & 5.19 & $38.81^{* *} \pm 0.51$ & 3.07 & 42 \\
$A I A$ & $4.28^{* *} \pm 0.36$ & 11.08 & $4.90^{* *} \pm 0.19$ & 11.63 & 7 \\
$C a$ & $0.63^{* *} \pm 0.19$ & 82.06 & $0.88^{* *} \pm 0.07$ & 17.47 & 2.5 \\
$P$ & $0.46^{* *} \pm 0.34$ & 18.01 & $0.36^{*} \pm 0.02$ & 17.10 & 0.30 \\
\hline
\end{tabular}

Each value is the average of 30 observations. $*(\mathrm{P}<0.05), * *(\mathrm{P}<0.01)$.

Table 3: Mean Chemical composition of different wheat bran (WB) samples

\begin{tabular}{llllll}
\hline & Branded WB & & Unbranded WB & & BIS (1992) \\
\hline & Mean \pm SE & CV (\%) & Mean \pm SE & CV (\%) & \\
\hline Moisture & $9.70 \pm 0.21$ & 9.19 & $9.77^{*} \pm 0.20$ & 4.24 & 10 \\
$C P$ & $13.85^{*} \pm 0.29$ & 5.80 & $9.97^{* *} \pm 0.25$ & 5.12 & 13 \\
$E E$ & $3.08 \pm 0.15$ & 19.47 & $2.94^{*} \pm 0.21$ & 14.21 & 3 \\
$C F$ & $9.78^{* *} \pm 0.23$ & 5.62 & $14.20^{* *} \pm 0.75$ & 10.64 & 12 \\
$N F E$ & $67.99^{* *} \pm 1.26$ & 6.98 & $67.68^{* *} \pm 0.57$ & 1.69 & 66 \\
$T A$ & $4.35^{* *} \pm 0.19$ & 13.45 & $4.78^{* *} \pm 0.27$ & 11.67 & 6 \\
$A I A$ & $0.44^{* *} \pm 0.12$ & 66.12 & $0.73^{* *} \pm 0.15$ & 37.07 & 0.25 \\
$C a$ & $0.16^{* *} \pm 0.23$ & 95.88 & $0.09^{* *} \pm 0.01$ & 25.76 & 0.13 \\
$P$ & $1.09^{*} \pm 0.34$ & 8.36 & $0.82^{* *} \pm 0.06$ & 17.64 & 1.20 \\
\hline
\end{tabular}

Each value is the average of 30 observations. *(P<0.05), ** $(\mathrm{P}<0.01)$.

adulteration of some high fibrous material. The values of CP reported by Rane et al. (1987) were well comparable to the present study, whereas, higher levels of CP were reported by and Adeyemo and Longe (2008), while Babayeni and Bamikole (2006) reported values lower then the BIS (2003a) specifications. The EE contents were higher in present study and similar findings were also reported by, Preston (2002), whereas lower values of EE were reported by Adeyemo and Longe (2008). Similar to the higher values of CF in the present study, Preston (2002) also reported same, whereas lower values were observed by Mudgal et al. (2003), Adeniji and Ehinmidu (2007) and Adeyemo and Longe (2008). The lower values of NFE presented in the study were also got confirmed by the findings of Mandal et al. (2002), while the values within the range was reported by, Adeyemo and Longe (2008). The lower values of TA and AIA in the present study were also reported by Adeyemo and Longe (2008), while the level of TA and AIA was observed with in the range in the studies of Mudgal et al. (2003). Values of Ca remained higher in present studies which were in agreement with the findings of Mandal et al. (2002). Whereas, reports of Preston (2002) revealed lower values of $\mathrm{Ca}$ In finding of present study the levels of $\mathrm{P}$ remained with in the range of standard and the reports of Reddy (2001). Whereas lower (Preston, 2002) values of P (compared to BIS, 2003a) were also been reported by other workers.

The chemical composition of branded and unbranded wheat bran samples are given in Table 3.

The results reported by Butt et al. (2004) were in agreement with the results of present study where similar values of moisture were found. The values of CP remained higher (branded) and lower (unbranded) then 
the recommendations of BIS (1992). Higher values of CP were also reported by Babikar et al. (2009), whereas the values of $\mathrm{CP}$ were reported with in range by some workers (Reddy, 2001; Tahir, 2002). The results of Tiwary et al. (2007) support the findings of present study where similar values of EE were observed, while higher values of EE were reported by Babikar et al. (2009) reported lower values of EE. The value of CF were lower (branded) and higher (unbranded) to the specifications of BIS (1992) and similarly lower values of CF were also reported by Babikar et al. (2009), while the values reported by Mudgal et al. (2003) were as per the recommendations of BIS (1992).

In present study higher values of NFE were observed and remained in agreement with results of Tiwary et al. (2007). Whereas the reports of Babikar et al. (2009), revealed lower values of NFE, while the values reported by Reddy (2001) were as per the specifications of BIS (1992). Similar to present findings lower values of TA was reported by Donkoh and Kotoku (2009), whereas Tahir (2002) reported higher values of TA, while the values reported by Babikar et al. (2009) were as per the specifications of BIS (1992).

The values of $\mathrm{Ca}$ for wheat bran reported in present study were higher (branded) and lower (unbranded) to the specifications (BIS, 1992) and higher values were also reported by Babikar et al. (2009) reported lower values of $\mathrm{Ca}$, while the values reported by Preston (2002) were in agreement to BIS (1992) specification. Reddy (2001), Mudgal et al. (2003) and Singh and Kundu (2003) observed lower values of P and were in agreement with the reports of present study, whereas higher values of $\mathrm{P}$ were reported by Babikar et al. (2009) where as per the specifications of BIS (1992).

The chemical composition of compounded feed samples is given in Table 4.

In present study, lower values of moisture were observed in contrast to the reports of Jain and Tiwari (2006), where higher values of moisture were recorded. CP values of branded compounded feeds were found with in the specifications of BIS (2003b), whereas the unbranded were having lower $(\mathrm{P}<0.01) \mathrm{CP}$. In agreement lower $\mathrm{CP}$ values were also reported by Mudgal et al. (2003) and Jain and Tiwari (2006). The values of EE were lower $(\mathrm{P}<0.05)$ in unbranded, while higher $(\mathrm{P}<0.01)$ in branded compounded feed samples then the BIS (2003b) specifications. The results reported by Jain and Tiwari (2006) were in agreement with the results of branded compounded feeds where higher values of EE were found, while values of EE were reported comparable to standard specifications of BIS (2003b) by Mudgal et al. (2003).

The values of CF were very high in unbranded samples, while lower for branded samples, which were supported by the study of Tiwary et al. (2007), while the values reported by Jain and Tiwari (2006) were in agreement for unbranded samples. Jain and Tiwari (2006) revealed values of NFE as per the specifications of BIS (2003b). Jain and Tiwari (2006) also revealed higher values of TA

Table 4: Mean Chemical composition of different compounded feed (CF) samples

\begin{tabular}{llllll}
\hline & Branded CF & & Unbranded CF & & BIS (2003) (Type II) \\
\hline & Mean \pm SE & CV (\%) & Mean \pm SE & CV (\%) & \\
\hline Moisture & $9.96^{* *} \pm 0.34$ & 7.84 & $9.97^{* *} \pm 0.38$ & 10.27 & 11 \\
$C P$ & $20.57 \pm 0.91$ & 9.94 & $13.21^{* *} \pm 0.73$ & 10.51 & 20 \\
$E E$ & $3.24^{* *} \pm 0.45$ & 31.38 & $2.18^{*} \pm 0.15$ & 14.18 & 2.5 \\
$C F$ & $10.22^{* *} \pm 0.22$ & 4.85 & $20.58^{* *} \pm 1.21$ & 11.07 & 12 \\
NFE & $52.76^{* *} \pm 0.62$ & 2.63 & $47.56^{* *} \pm 1.08$ & 4.19 & 57 \\
$T A$ & $12.25^{* *} \pm 0.82$ & 14.83 & $17.70^{* *} \pm 0.99$ & 10.73 & 9 \\
AIA & $2.77^{* *} \pm 0.40$ & 32.39 & $11.49^{* *} \pm 0.87$ & 14.35 & 4 \\
$C a$ & $0.89^{* *} \pm 0.05$ & 17.71 & $0.89^{* *} \pm 0.03$ & 8.63 & 0.5 \\
$P$ & $0.76^{* *} \pm 0.39$ & 27.59 & $0.73^{* *} \pm 0.06$ & 15.89 & 0.5 \\
Urea & $0.96 \pm 0.13$ & 28.54 & $1.28^{* *} \pm 0.05$ & 7.97 & 1 \\
\hline
\end{tabular}

Each value is the average of 30 observations. $*(\mathrm{P}<0.05), * *(\mathrm{P}<0.01)$. 
in agreement with the present study, whereas the reports of Mudgal et al. (2003) observed values of TA as per the BIS (2003b) specifications.

Lower values of AIA were observed in branded samples, while the values for unbranded samples was very high, represents the adulteration, Similar to the present findings higher values of $\mathrm{Ca}$ were observed by Mudgal et al. (2003), whereas lower values of Ca were reported by Jain and Tiwari (2006). In agreement to the present findings higher values of $\mathrm{P}$ were also reported by Jain and Tiwari (2006),

\section{CONCLUSION}

It may be concluded that in Indore district of Madhya Pradesh feeding pattern of dairy animals was not up to the mark and cotton seed cake, wheat bran and complete feeds are the main concentrate feeds in their ration. The samples of CSC, WB and CF having nutritive value below their required specifications (BIS) especially in case of unbranded samples, while the branded once were almost within their expectations except the amount of total ash in compounded feeds, which remained higher then recommended. The unbranded samples of these feeds were usually lower in protein and high in crude fiber but especially the compounded feeds were very high in total ash and acid insoluble ash remains indicative of adulterations. Hence BIS have to tack strict initiatives to control the quality of concentrate feeds and among them complete feed requires special attention to be paid.

\section{ACKNOWLEDGEMENTS}

The authors are thankful to the NDVSU, Jabalpur for the fund for carrying out this research work.

\section{REFERENCES}

Adeyemo, G.O. and Longe, O.G. 2008. Effects of cotton seed cake based diets on performance and egg quality characteristics of layers. Pakistan J. Nutri., 7: 597-602.

AOAC, 1995. Official Methods of Analysis, $15^{\text {th }}$ ed. Association of Official Analytical Chemists, Washington, D.C.

Babayeni, O.J. and Bamikole, M.A. 2006. Nutritive value of Tefrosia candida seeds in West African dwarf goats. J. Cent. Eur. Agric., 7: 731-738.
Babikar, M.S., Kijora, C., Abbas, S.A. and Danier, J. 2009. Nutrient composition of main feed ingredients used in Sudan and their variations from local standard table values. Int. $J$. Poult., Sci., 8: 355-358.

BIS 1992. Bureau of Indian standard (IS: 2239). First revision wheat bran for livestock, pp. 3.

BIS 2003a. Bureau of Indian standard (IS: 1712). Fourth revision cotton seed cake for livestock, pp. 2.

BIS 2003b. Bureau of Indian standard (IS: 1508). Fifth revision compounded feeds for livestock, pp. 5.

Donkoh, A. and Kotoku, V.A. 2009. Nutritive values of feed stuffs for poultry in Ghana: chemical composition, apparent metabolizable energy and ileal amino acid digestibility. $J$. Anim. Feed Sci., 19: 1120-1132.

Jain, R.K. and Tiwari, S.P. 2006. Nutritional quality of some of the commercial dairy concentrate mixtures and feeds for pigs, poultry and fish of Chhattisgarh state. In: Proc. XI Animal Nutrition Conference, Jabalpur : 5.

Lohan, O.P., Chahal, S.M. and Kishore, N. 1998. Feed Quality Evaluation Techniques. CCS Haryana Agricultural University Press. Hisar, pp. 48-49.

Mandal, A.B., Yadav, P.S. and Sunaria, K.R. 2002. Nutritional status of Mohindergarh district of Haryana. Indian J. Anim. Sci., 72: 1149-1152.

Mudgal, V., Mehta, M.K., Rane, A.S. and Nanavati, S. 2003. A survey on feeding practices and nutritional status of dairy animals in Madhya Pradesh. Indian J. Anim. Nutr., 20(2): 217-220.

Preston, R.L. 2002. Typical composition of commonly used feeds for sheep and cattle. Feed Composition Guide.

Rane, A.S., Mehta, M.K., Jain, R.K. and Bhaid, M.U. 1987. To study variation in chemical composition of different concentrate ingredients. Livestock Advisor, 4(11): 5- 11.

Reddy, D.V. 2001. Principles of Animal Nutrition and Feed Technology. Oxford and IBH Publishing Co. Pvt. Ltd., New Delhi, pp. 355.

Sharma, P. and Jain, R.K. 2016. Feeding Pattern During Advanced Pregnancy and Incidence of Reproductive and Metabolic Disorders in Crossbred Cows. J. Anim. Res., 6(5): 843-848.

Singh, R. and Kundu, S.S. 2003. Quality evaluation of some animal feedstuff available in Haryana. Anim. Nutr. Feed Technol., 3: 151-158.

Snedecor, G.W. and Cochran, W.G. 1994. Statistical methods. $8^{\text {th }}$ ed. Lowa State University Press, New York, USA. 
Tahir, M.I., Kahalique, A., Pasha, T.N. and Bhatti, J.A. 2002. Comparative evaluation of maize bran, wheat bran and rice bran on milk production of Holstein Friesian cattle. Int. J. Agri. Biol., 4: 559-560.
Tiwary, M.K., Tiwari, D.P., Kumar, A. and Mondal, B.C. 2007. Existing feeding practices, nutrient availability and reproductive status of dairy cattle and buffaloes in Haridwar district of Uttarakhand. Anim. Nutr. Feed Technol., 7(2): 177186 